\title{
Taiwanese primary school teachers' perceived enablers for and barriers to the integration of children's literature in mathematics teaching and learning
}

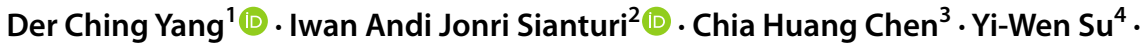 \\ Natthapoj Vincent Trakulphadetkrai ${ }^{5}$ (D)
}

Accepted: 3 October 2021 / Published online: 29 November 2021

(C) The Author(s) 2021

\begin{abstract}
This study is part of the international survey studies on teachers' beliefs concerning the integration of children's literature in mathematics teaching and learning, and this paper reports the findings of the thematic analysis of open-ended survey responses elicited from 287 primary school teachers and teacher trainees in Taiwan. Using the seminal social psychology theory, the Theory of Planned Behaviour (Ajzen in Organizational Behavior and Human Decision Processes, 50, 179-211, 1991) to frame the findings, this study highlights 11 perceived barriers and 11 perceived enablers that are thought to influence the teachers' intention to integrate children's literature in their mathematics teaching. More specifically, we identified time constraint, lack of pedagogical knowledge and confidence, and resource constraint as being the most-cited perceived barriers, while pedagogical benefits, desire to improve teaching, and enabling social norms were identified as the top perceived enablers. Ultimately, this article offers several recommendations to address some of these key perceived barriers.
\end{abstract}

Keywords Children's literature · Barriers and enablers · Mathematics teacher education · Theory of Planned Behaviour (TPB) · Teachers' beliefs

\section{Introduction}

While mathematics and literacy may have been viewed as two separate domains, educational stakeholders, particularly in the United States, have attempted to bring these two domains closer together over the past three decades through the use of children's literature, especially in the form of story picture books (National Council of Teachers of Mathematics [NCTM], 1992, 2004, 2018). However, in the context of Taiwan where the current study is situated, mathematics teachers are explicitly encouraged to integrate mathematics and literacy through mathematics story picture book integration (數學繪本融入) only recently (Ministry of Education in Taiwan [MET], 2019) based on two major concerns. Firstly, although Taiwanese

Natthapoj Vincent Trakulphadetkrai

n.trakulphadetkrai@reading.ac.uk

Extended author information available on the last page of the article 
students performed satisfactorily in international mathematics assessments, they continue to exhibit negative attitudes towards mathematics (Mullis et al., 2016, 2020), which has drawn the attention of policymakers in Taiwan. To address such concerns, the MET is encouraging mathematics teachers in Taiwan to design mathematics teaching and learning that are appealing to and potentially generate a meaningful learning for students, which could be manifested using children's literature (e.g., story picture books). Earlier studies suggested that the use of story picture books in mathematics teaching and learning could help foster children's positive attitude towards mathematics learning (e.g., Clarke, 2002; Huang \& Yang, 2021; McAndrew et al., 2017). Secondly, Taiwan's new Mathematics Curriculum for Grades 1 to 12 (MET, 2019) put more emphasis on developing mathematical literacy, advocating that more contextual teaching and learning using daily-life situation (practical situation) should be integrated into mathematics teaching and learning. For young children, using story picture books in mathematics teaching and learning is considered a promising way to promote their mathematical literacy (Altieri, 2010; Casey et al., 2004; van den Heuvel-Panhuizen et al., 2016).

Considering substantial benefits of integrating children's literature in mathematics teaching and learning as presented in section 2, the integration could be useful to help Taiwanese teachers manifest the objectives of Taiwan's current mathematics curriculum: to cultivate students' confidence and positive attitude in exploring mathematics and to develop mathematical knowledge required for everyday life (MET, 2019). Taiwanese teachers are explicitly encouraged to enrich mathematics teaching and learning and to provide more access to mathematics using children's literature or story picture books (MET, 2019). Nevertheless, this policy might not always be translated to actual practice. Given that teachers' beliefs about mathematics teaching and learning can shape their mathematics teaching practice (Polly et al., 2013), teachers' beliefs cannot be overlooked and should be properly taken into consideration. This is in line with what Pajares (1992), a pioneering figure in the research field of teachers' beliefs, argued: "the beliefs teachers hold influence their perceptions and judgments, which, in turn, affect their behaviour in the classroom" (p. 307). These arguments reinforce the importance of examining teachers' beliefs when intending to understand teachers' instructional practices in mathematics.

Teachers' beliefs concerning the integration of children's literature in mathematics instruction have been largely under-researched (Prendergast et al., 2019), and the few studies available in the literature were conducted in Western socio-cultural contexts; no research has been conducted to examine such a topic in the Asian social-cultural context, especially with regard to Taiwanese teachers' beliefs concerning the integration of children's literature in mathematics teaching and learning. Accordingly, a study that focuses on such teachers' beliefs in Taiwan is indispensable because beliefs are arguably different depending on cultures and contexts (Chan \& Elliot, 2004), and we cannot always rely on findings from studies conducted in a different socio-cultural context to represent either Taiwanese or Asian teachers' beliefs. This is particularly in line with the construct of cultural beliefs asserted in Bussi et al.'s (2020) study, in which an individual's belief might be different from others' beliefs concerning an issue/phenomenon depending on their cultures. Thus, the present study is put in the position of understanding better the cultural beliefs that support the integration and of making the researchers and practitioners aware of them. 


\section{Literature review}

\subsection{Children's literature and mathematics}

In the context of this study, children's literature is considered as texts that are "usually shorter, $[\ldots]$ with dialogue and incident rather than description and introspection; child protagonists are the rule; [...] language is child-oriented" (McDowell, 1976, pp. 141-142) and that can either contain an explicit mathematical focus or without it (Trakulphadetkrai, 2018). Following the National Council of Teachers of Mathematics' ([NCTM], 2000) recommendation that students should do more reading, writing, and discussion of ideas in mathematics teaching and learning and learn mathematical ideas in real-world contexts, several studies have been conducted to scrutinize the impact of using children's literature in mathematics teaching and learning (e.g., Bintz et al., 2011; Casey et al., 2004; HassingerDas et al., 2015; van den Heuvel-Panhuizen et al., 2016).

Through a review of research literature, NCTM (2018) identifies a wide range of benefits of the integration including fostering positive attitudes towards learning mathematics, fostering mathematical discourse, deepening conceptual understanding, and helping students access prior knowledge. Earlier studies (e.g., Hassinger-Das et al., 2015; Purpura et al., 2017) also have reported that the integration of children's literature into mathematics helps develop children's language skills, particularly enriching their (mathematical) vocabulary knowledge. From the perspective of mathematics educators, the integration facilitates an opportunity to enjoy reading and learning mathematics simultaneously (Bintz et al., 2011; Casey et al., 2004), helps connect abstract languages and concepts of mathematics to real-world contexts (van den Heuvel-Panhuizen et al., 2016), build mathematical thinking and reasoning (Burns, 1992; van den Heuvel-Panhuizen \& Elia, 2013), and develop important problem-solving abilities that would continue to assist children throughout their life (Moyer, 2000; van den Heuvel-Panhuizen et al., 2016). For instance, as story picture books provide meaningful contexts relevant to and visual illustrations of mathematical concepts, students could foster critical thinking skills sustained by the opportunities to apply mathematical knowledge when solving problems relevant to their real-life situation (Elia et al., 2010; van den Heuvel-Panhuizen et al., 2016). Throughout the past few decades, studies also have shown that the use of children's literature in mathematics teaching and learning can increase students' mathematics achievement (Hong, 1996; Jennings et al., 1992; Kisker et al., 2012). This is particularly reasonable as children's language skills have been found to have a strong connection to their mathematical ability (e.g., Trakulphadetkrai et al., 2020). Therefore, integrating children's literature in mathematics teaching and learning could enable students to gain a better understanding of mathematical concepts, demonstrate the practical applications of mathematics, and illustrate how mathematical concepts are presented in concrete settings that are appealing to them.

In the context of Taiwan, although relevant studies are very limited, the integration of children's literature in mathematics teaching is found to generate certain pedagogical benefits for students. For instance, as a pedagogical strategy, Chen et al. (2013) designed mathematical activities that use story picture books for second-grade students ( 7 to 8 years old) when learning multiplication. The results confirmed that mathematics teaching blended with story picture books could effectively promote students' learning motivation and learning efficiency. Chen et al. (2013) also conducted individual interviews with four elementary school teachers to further examine teachers' views concerning the contents and effects of the mathematical activities. Findings showed that the teachers believe that the teaching 
mode which integrates children's literature in mathematics teaching and learning is feasible and suitable to be incorporated in their future teaching, and therefore, they will consider implementing such a teaching mode. In addition, Huang and Yang (2021) developed and applied two sets of non-commercial Taiwanese mathematical story picture books in a fourth-grade mathematics class involving 14 students ( 9 to 10 years old). The findings showed that story picture books can help children develop mathematical concepts and promote positive attitudes toward mathematics.

A plethora of children's literature in the story picture book format for mathematics teaching and learning has been released onto the market across the world including Taiwan. Currently, there are, at least, over 200 mathematical story picture books in Mandarin Chinese, and the majority of which are translated from English (e.g., MathStart [數學啓 蒙, 63 titles], Math Matters [數學幫幫忙繪本, 36 titles], Mouse Math [鼠小弟愛數學, 20 titles]), and Korean (e.g., 從小愛數學 [Love Maths Since Childhood, 40 titles], 數學繪 本 (Math Picture Book, 36 titles], 好玩的數學繪本 [Fun Math Picture Book, 30 titles]). These mathematical story picture books can be used to cover a wide range of mathematical topics for a wide range of age groups. For example, Ali Baba Forty Thieves [阿里巴巴與 四十大盜] provides a story to teach number less than 100, and Let's Draw a Moon [分類 大家來畫月亮] is useful to teach the concepts of a circle for younger children. For older children, The Doorbell Rang [門鈴又響了] is helpful to teach division, and Spaghetti and Meatballs for All [義大利麵與肉丸子] can be used to teach perimeter.

\subsection{Teachers' beliefs concerning the use of children's literature in mathematics teaching and learning}

Despite the positive effects of integrating children's literature in mathematics teaching and learning, bringing this integration into actual practice largely depends on teachers' perceptions and willingness to incorporate the literature in mathematics instructions (Polly et al., 2013; Prendergast et al., 2019). Moyer (2000) also highlighted that classroom practice and teachers' strategies have not always promoted and reflected upon this integration in mathematics teaching, indicating the importance of exploring teachers' beliefs and perceptions concerning the integration. Nevertheless, there are only two empirical studies that have attempted to explore teachers' beliefs regarding the integration in mathematics education (i.e., Alazzi, 2006; Prendergast et al., 2019). Firstly, using a phenomenological approach to analyze data collected via a survey, Alazzi's (2006) study scrutinized the perceptions of 85 pre-service primary teachers who enrolled at a Midwestern university in the USA on the use of three children's story picture books for teaching geometrical contents. The study sought to examine teachers' views on the literature and the effects of the viewpoints on using the literature in mathematics teaching and learning. Concerning the perceptions, the results showed six different themes including making personal connections with the literature, reading for children, being a teacher, looking for the math, finding instructional ideas, and focusing on morals. Secondly, Prendergast et al.'s (2019) survey study explored the perceptions of 154 pre-service and in-service primary school teachers in Ireland and revealed several themes of perceived enablers for and barriers to the integration. The perceived enablers included perceived pedagogical benefits, enabling social norms, and love of children's literature. The perceived barriers comprised resource constraints, time constraints, lack of pedagogical knowledge and confidence, doubts about outcome expectancy, and inhibiting social norms. 
As noted earlier, teachers' beliefs are arguably different depending on cultures and contexts (Bussi et al., 2020; Chan \& Elliot, 2004). Thus, we elaborate on some critical differences of cultures and contexts relevant to mathematics teaching and learning held by people in East Asian (represented by Taiwan in this study) and Western countries as reported in the earlier studies (e.g., Graf \& Leung, 2000; Leung, 2001; Lui \& Leung, 2012). Leung (2001) discussed the cultural differences from six dichotomies. The first is "Product (content) versus process" (Leung, 2001, p. 38): East Asians highlight the results of mathematics learning (product) which is deemed as evidence that the mathematics teacher has helped students acquire the intended mathematics contents. In particular, getting a high score in mathematics assessment is much more important than knowing the process to arrive at the results. However, Westerners put more emphasis on the learning process (for instance, doing mathematics) which emphasizes a distinctive way or process of dealing with reality. The second is "Rote learning verse meaningful learning" (Leung, 2001, p. 39): East Asians put more emphasis on memorizing the rules and facts to solve mathematics problems quickly and correctly without highlighting related conceptual understanding. On the other hand, Westerners view that mathematics learning should target the development of conceptual understanding by emphasizing that students should first understand a concept before committing information to memory, if the memorization is necessary at all. The third is "Study hard versus pleasurable learning" (Leung, 2001, p. 41): East Asians believe that studying is a serious endeavor justifying that the route to success lies in hard work, requiring students to work hard and maintain perseverance in their study. If students want to obtain high mathematics scores and enter good senior high schools or good universities, they need to work hard. In contrast, Westerners generally believe that mathematics learning should generate pleasurable learning experiences, and students should exhibit positive attitudes towards mathematics. The fourth is "Extrinsic versus intrinsic motivations" (Leung, 2001, p. 42): East Asian students experience high pressure when learning mathematics, as mathematics teaching and learning in school is typically designed with an exam-oriented setting. Therefore, East Asian students (e.g., Chinese, Taiwanese, and Korean students) tend to exhibit negative attitudes towards mathematics (Mullis et al., 2016, 2020). In contrast, Westerners believe that the best way to motivate students to engage in mathematics learning is through getting them interested in mathematics and making them feel/see that learning mathematics is fun (Leung, 2001). The fifth is "Whole class teaching versus individual learning" (Leung, 2001, p. 44): Western education highlights the importance of independence and individual learning. Therefore, Western classes tend to show a student-centered setting. On the other hand, East Asian classes tend to exhibit a teacher-centered setting, highlighting the essence of whole class teaching. The sixth is "Competence of teachers: Subject matter versus pedagogy" (Leung, 2001, p. 45): Westerners view the role of teachers as a facilitator of learning; however, East Asians believe that mathematics teachers play a key role in mathematics classes.

Based on these cultural dimensions, cultural differences, particularly those relevant to mathematics teaching and learning, can be said to play an essential role in shaping teachers' beliefs on the integration of children's literature in mathematics teaching and learning. Given how the previous studies on the topic (Alazzi, 2006; Prendergast et al., 2019) were conducted in the Western socio-cultural context, it is of great importance that the perspectives and voices of Asian teachers, particularly Taiwanese teachers in the context of the current study, are also heard. 


\subsection{Theoretical framework}

The current study frames teachers' beliefs concerning the integration of children's literature in mathematics teaching and learning using the social psychology theory called the Theory of Planned Behaviour [TPB]. The TPB is a theoretical framework designed by Ajzen (1991) to predict and explain human behavior. The TPB has been used as a means to predict the intentions of teachers to actively engage in on-going professional development concerning teaching and learning and to modify teaching practices as a result of such development process (Underwood, 2012). The TPB considers beliefs to play either a facilitating or an inhibiting role in reform efforts implemented for mathematics teaching and learning (Handal \& Herrington, 2003), which may either enable or present barriers to a person's intention to change. The TPB posits three constructs (i.e., attitude toward the behavior, subjective norm, and perceived behavioral control), which could be directly associated with teachers' perceived enablers and barriers (Prendergast et al., 2019).

Attitude toward the behavior refers to "the degree to which a person has a favorable or unfavorable evaluation or appraisal of the behaviour in question" (Ajzen, 1991, p. 118). Handal and Herrington (2003) asserted that each teacher holds a particular belief system related to education system, the curriculum, and teaching approach, and such belief system guides the teacher to select and assign a teaching practice (e.g., integrating children's literature in mathematics teaching and learning). Subjective norm refers to the "perceived social pressure to perform or not to perform a behaviour" (Ajzen, 1991, p. 118); this norm concerns whether others would approve or disapprove of one's behavior, or in the context of teachers, of one's teaching practice (Underwood, 2012). The perceived behavioral control refers to an individual's perception of the ease or difficulty of performing the behavior of interest (Ajzen, 1991, 2012). The perceived behavioral control considers the beliefs in the abilities, resources, and opportunities to perform a behavior. In the context of teaching and learning, perceived behavioral control concerns teachers' perception of having control over both external and internal factors that influence their teaching, such as teaching time, related teaching materials, and feelings of personal capability and security/insecurity (Nordlöf et al., 2017). It is unlikely that mathematics teachers can modify their teaching practices to align with a reform effort without changing their beliefs (Leutwyler et al., 2014; Philipp, 2007). Therefore, in the context of this study, the TPB was employed as a means to examine the intentions of primary Taiwanese teachers to incorporate children's literature in mathematics teaching and learning by exploring their perceived enablers for and the perceived barriers to the implementation of such approach.

\subsection{The current study}

Drawing from the research gap as noted above, the current study set out to answer the following research question: What do in-service and pre-service primary school teachers in Taiwan perceive to be the key barriers to and enablers for the integration of children's literature in mathematics teaching and learning? That the study chose to focus on both in-service teachers and pre-service teachers is because both groups of teachers might have different sets of perceived barriers and enablers (e.g., pre-service teachers may be asked to follow lesson plans set by their mentor teachers at least early on in their teaching placement, and their teaching practices would thus be largely influenced by their mentor teachers). 


\section{Methods}

\subsection{Data collection}

To answer the research question, we collected data using an open-ended questionnaire, which was originally developed and piloted with 109 pre-service teachers in England, as reported in Trakulphadetkrai's (2015) study. The questionnaire was later used to collect data from 51 in-service teachers and 103 pre-service teachers in Ireland (Prendergast et al., 2019). The questionnaire contained four key sections: (1) asking participants to define and give examples of children's literature; (2) asking participants to write the first five thoughts that come into their mind when they think about the integration of children's literature in mathematics teaching and learning, (3) asking eight questions concerning their experience (if any) of implementing this integrative approach, (4) asking for contextual information about the participants.

The data reported in this paper were drawn from the participants' responses to two questions in the third section of the questionnaire: (1) in your experience, what are the key barriers that impede you from incorporating (more) children's literature in your mathematics teaching? (如你在本學年的數學教學中有把一些兒童文學的形式融入在數學課堂, 是 甚麼推動你這樣做?) and (2) if you have previously incorporated children's literature in your mathematics teaching, what concerns did enable/encourage you to do so? (在你的經 驗中, 有哪些主要因素會阻礙你將兒童文學融入在你的數學教學中?).

The questionnaire was translated from English to Taiwanese Mandarin by Authors 1, 3, and 4, and to ensure the reliability of the translation, these three authors checked one another's translation until an agreement was reached. The same process was also employed when translating the survey data to English after the data collection was completed. It is worth highlighting that 兒童 文學 was carefully chosen as the Taiwanese Mandarin translation of 'children's literature', as it is considered the commonly used translation for the term. As 兒童文學 is a common term, it was felt that there is no need to explain this term to the survey respondents on the questionnaire (that said, please read our reflection on the use of this translated term in section 5). The ethics clearance for this study was sought and granted by the first author's institution. We also provided all respondents with a Teacher Information Sheet preceding the questionnaire and a brief overview of the study, and the collected data has been anonymized and stored securely.

\subsection{Study participants}

Overall, 321 in-service teachers and 102 pre-service teachers across Taiwan were invited to take part in the present study. In total, 287 survey participants responded, including 190 inservice teachers and 97 pre-service teachers (most of whom were in the final year of their undergraduate teacher training degree), representing the response rates of $59.2 \%$ and $95.1 \%$ respectively. As Table 1 illustrates, there were more female teachers than male teachers within each cohort. These teacher participants teach Grades 1 to 6, and a larger number of the participants teach Grades 6, 4, and 2. Over half of the in-service teachers in this study have had around 11 to 20 years of teaching experience.

Responding to the question that inquired how frequently they have incorporated children's literature as part of their mathematics teaching in the current academic year, over $70 \%$ of the participants indicated that they have never done so. On the other hand, only $2.1 \%$ of the survey respondents (i.e., only one pre-service teacher and five in-service teachers) reported that they have used children's literature frequently in their mathematics 
Table 1 Demographic characteristics of the survey participants

\begin{tabular}{|c|c|c|c|}
\hline & $\begin{array}{l}\text { Total } \\
(N=287)\end{array}$ & $\begin{array}{l}\text { In-service teachers } \\
(N=190)\end{array}$ & $\begin{array}{l}\text { Pre-service } \\
\text { teachers } \\
(N=97)\end{array}$ \\
\hline Characteristics & $n(\%)$ & $n(\%)$ & $n(\%)$ \\
\hline \multicolumn{4}{|l|}{ Sex } \\
\hline Male & $54(18.8 \%)$ & $37(19.5 \%)$ & $17(17.5 \%)$ \\
\hline Female & $233(81.2 \%)$ & $153(80.5 \%)$ & $80(82.5 \%)$ \\
\hline \multicolumn{4}{|l|}{ Class taught } \\
\hline Grade 1 (6-7 years old) & $3(1 \%)$ & $1(0.5 \%)$ & $2(2.1 \%)$ \\
\hline Grade 2 ( $7-8$ years old $)$ & $53(18.5 \%)$ & $33(17.4 \%)$ & $20(20.6 \%)$ \\
\hline Grade 3 ( $8-9$ years old $)$ & $32(11.1 \%)$ & $21(11.1 \%)$ & $11(11.3 \%)$ \\
\hline Grade 4 (9-10 years old) & $63(21.9 \%)$ & $35(18.4 \%)$ & $28(28.9 \%)$ \\
\hline Grade 5 (10-11 years old) & $44(15.3 \%)$ & $29(15.3 \%)$ & $15(15.5 \%)$ \\
\hline Grade 6 (11-12 years old) & $68(23.7 \%)$ & $51(26.8 \%)$ & $17(17.5 \%)$ \\
\hline A wide range of class levels & $24(8.4 \%)$ & $20(10.5 \%)$ & $4(4.1 \%)$ \\
\hline \multicolumn{4}{|l|}{ Teaching experience level (years) } \\
\hline $1-10$ & $\mathrm{n} / \mathrm{a}$ & $55(28.9 \%)$ & $\mathrm{n} / \mathrm{a}$ \\
\hline $11-20$ & $\mathrm{n} / \mathrm{a}$ & $96(50.5 \%)$ & $\mathrm{n} / \mathrm{a}$ \\
\hline $21-30$ & $\mathrm{n} / \mathrm{a}$ & $38(20 \%)$ & $\mathrm{n} / \mathrm{a}$ \\
\hline$>30$ & $\mathrm{n} / \mathrm{a}$ & $1(0.5 \%)$ & $\mathrm{n} / \mathrm{a}$ \\
\hline \multicolumn{4}{|c|}{$\begin{array}{l}\text { Whether training on using children's literature in mathematics teaching is/was provided as part of teach- } \\
\text { ing training }\end{array}$} \\
\hline Yes & $43(15 \%)$ & $34(17.9 \%)$ & $9(9.3 \%)$ \\
\hline No & $230(80.1 \%)$ & $142(74.7 \%)$ & $88(90.7 \%)$ \\
\hline Cannot remember-too long ago & $14(4.9 \%)$ & $14(7.4 \%)$ & $\mathrm{n} / \mathrm{a}$ \\
\hline \multicolumn{4}{|c|}{ Frequency of using children's literature in mathematics teaching within the current academic year } \\
\hline Never & $207(72.1 \%)$ & $130(68.4 \%)$ & $77(79.4 \%)$ \\
\hline Infrequently (1-10 lessons) & $74(25.8 \%)$ & $55(28.9 \%)$ & $19(19.6 \%)$ \\
\hline Frequently (> 10 lessons) & $6(2.1 \%)$ & $5(2.6 \%)$ & $1(1 \%)$ \\
\hline
\end{tabular}

teaching (i.e., more than 10 mathematics lessons), while the other $25.8 \%$ rarely used children's literature (i.e., only 10 mathematics lessons or less). Concerning the responses to the question asking whether any training on using children's literature in mathematics teaching was given as part of their teaching training, the majority of the in-service teachers $(74.7 \%)$ and, to a greater extent, the pre-service teachers (90.7\%) reported that no such training was or has been provided to them.

\subsection{Data analysis}

While the study adopted the TPB theory to help frame our discussion, the theory did not dictate the design of our questionnaire, as the survey questions used in this study 
are open-ended in nature (see section 3.1). Moreover, we did not want to code our perceived barriers and enablers deductively using the theory's three elements (i.e., attitude toward the behavior, subjective norm, and perceived behavioral control), as that would be too broad. Instead, the open-ended questionnaire data were analyzed thematically and inductively using a constant comparative method to allow perceived barriers and enablers specific to this study to emerge. The TPB was later used solely to frame our discussion of the different themes generated from the data.

For data analysis, any written responses that were vague, ambiguous, or not specifically relevant to either perceived barriers or enablers (e.g., "For the children's learning") were discarded during the data preparation stage.

During the analysis, the focus was first on identifying "categories", so that similar categories could then be grouped together into a set of coherent themes. For example, these three categories: Limited or lack of training and experience in the approach, Limited or lack of awareness of suitable children's literature for specific mathematical concepts, and Perceived difficulty and/or fear in implementing the approach were later grouped together under a theme labeled Lack of Pedagogical Knowledge and Confidence. To capture how often each of these categories was mentioned by the survey respondents, descriptive statistics were used. The survey respondents were able to state more than one perceived barrier and enabler, but any beliefs repeated by the same respondents were not counted twice.

Each category itself is made up of teachers' responses relevant to that particular category. For example, the category, "Encouraged and inspired by teacher's own perception that teaching mathematics through children's literature makes the teaching more engaging and fun" is made up of teachers" responses, such as "I want to arouse student's learning motivation", "Generating interests in learning", and "Increase interest in learning". This stage of analysis was achieved through several rounds of reading and re-reading the responses. It is also worth noting that, in a few cases, more than one category could be found in a single sentence. For example, when a teacher responded/wrote: "Interesting and can be used to arouse motivation", through the process of moderation, it was agreed that the first part of the sentence would be coded under the Encouraged and inspired by teacher's own perception that teaching mathematics through children's literature is an interesting and innovative concept category, while the second part of the sentence would be coded as the Encouraged and inspired by teacher's own perception that teaching mathematics through children's literature makes the teaching more engaging and fun category. In this vein, the unit of analysis is thus not necessarily always at the sentence level only but could be made up of a cluster of words within a sentence.

To ensure the coding reliability, both Author 1 and Author 5 coded all the data, and their coding results were then compared. Due to the nature of the data being openended and non-binary, the inter-coder agreement percentage was calculated instead of the Cohen's kappa coefficient. The inter-coder agreement percentages for the perceived barriers and enablers were relatively high ( $97.5 \%$ and $96.4 \%$ respectively), indicating that the coding frameworks that we have developed for this study's analysis were reliable (Tables 2 and 3). That said, we fully acknowledge that the key drawback of reporting inter-coder agreement percentages is how agreement that could have happened by chance was not taken into account, so interpretations of our reported inter-coder agreement percentages should be treated with caution. Any discrepancies and disagreements in coding were subsequently discussed until a coding agreement was reached. 
Table 2 Survey responses concerning perceived barriers to the integration of children's literature in mathematics teaching

\begin{tabular}{|c|c|c|c|c|}
\hline \multirow[t]{2}{*}{ Categories } & Examples of statement & $\begin{array}{l}\text { Total number of } \\
\text { teachers }(\mathrm{T}) \\
(N=256 / 287)\end{array}$ & $\begin{array}{l}\text { In-service } \\
\text { teachers (IST) } \\
(N=180 / 190)\end{array}$ & $\begin{array}{l}\text { Pre-service } \\
\text { teachers (PST) } \\
(N=76 / 97)\end{array}$ \\
\hline & & $f *(\%)$ & $f *(\%)$ & $f^{*}(\%)$ \\
\hline
\end{tabular}

Theme 1: time constraint $(53.1 \%)$

1. Limited or lack of
teaching time to incor-
porate the approach

"I think the teaching
hours are insufficient."

$100(33 \%)$

$69(31.9 \%)$

$31(35.6 \%)$

2. Limited or lack of time (unspecified)

"Not that much time."

$54(17.8 \%)$

$45(20.8 \%)$

$9(10.3 \%)$

3. Limited or lack of

"I need time to prepare

$7(2.3 \%)$

$7(3.2 \%)$

$0(0 \%)$

time to plan for lessons

the lessons."

using this approach

Theme 2: lack of pedagogical knowledge and confidence (22.8\%)

4. Limited or lack of
training and experience
in the approach

5. Limited or lack of awareness of suitable children's literature for specific mathematical concepts

6. Perceived difficulty and/or fear in implementing the approach
"I don't know how to

$47(15.5 \%)$ integrate the literature into math."

"There are few children's literature integrated into mathematics curriculum."

"It is difficult to connect [mathematics and children's literature]."

Theme 3: resource constraint (13.2\%)

7. Limited or lack of suitable children's literature for mathematics teaching at school

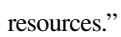

$40(13.2 \%)$
8. Perceived limitation of the approach for children with limited literacy proficiency and those not interested in reading

9. Perceived incompatibility between children's literature and mathematics teaching

10. Perceived incompatibility between the approach and the adopted mathematics textbooks, assessments, and school's ethos weak reading ability will reject it."

$17(5.6 \%)$

$8(3.7 \%)$ focus on story. Mathematics is more difficult to integrate into the style of literary works."

"Different direction of school teaching." 
Table 2 (Continued)

\begin{tabular}{|c|c|c|c|c|}
\hline Categories & Examples of statement & $\begin{array}{l}\text { Total number of } \\
\text { teachers }(\mathrm{T}) \\
(N=256 / 287) \\
f^{*}(\%)\end{array}$ & $\begin{array}{l}\text { In-service } \\
\text { teachers (IST) } \\
(N=180 / 190) \\
f^{*}(\%)\end{array}$ & $\begin{array}{l}\text { Pre-service } \\
\text { teachers (PST) } \\
(N=76 / 97) \\
f^{*}(\%)\end{array}$ \\
\hline \multicolumn{5}{|c|}{ Theme 5: inhibiting social norms (1.3\%) } \\
\hline $\begin{array}{l}\text { 11. Perceived unwilling- } \\
\text { ness of key stake- } \\
\text { holders (e.g., school } \\
\text { leaders, mentors, } \\
\text { or parents) for this } \\
\text { approach to be adopted }\end{array}$ & $\begin{array}{l}\text { "Disagreement of the } \\
\text { approach as expressed } \\
\text { by parents." }\end{array}$ & $4(1.3 \%)$ & $3(1.4 \%)$ & $1(1.1 \%)$ \\
\hline Total $(f)$ & & 303 & 216 & 87 \\
\hline
\end{tabular}

Note. $f$ is here taken to refer to the number of teachers who mentioned a particular belief. Beliefs repeated by the same teacher were only counted once. Participants were able to state more than one perceived barrier, which explains why the total number of $f(303)$ exceeded the total number of teachers who responded to the survey question $(N=256)$

Table 3 Survey responses concerning perceived enablers for the integration of children's literature in mathematics teaching

\begin{tabular}{|c|c|c|c|c|}
\hline Categories & $\begin{array}{l}\text { Examples of } \\
\text { statement }\end{array}$ & $\begin{array}{l}\text { Total number of } \\
\text { teachers }(\mathrm{T}) \\
(N=185 / 287) \\
f^{*}(\%)\end{array}$ & $\begin{array}{l}\text { In-service } \\
\text { teachers (IST) } \\
(N=111 / 190) \\
f^{*}(\%)\end{array}$ & $\begin{array}{l}\text { Pre-service } \\
\text { teachers (PST) } \\
(N=74 / 97) \\
f^{*}(\%)\end{array}$ \\
\hline \multicolumn{5}{|c|}{ Theme 1: perceived pedagogical benefits (53.4\%) } \\
\hline $\begin{array}{l}\text { 1. Encouraged and inspired } \\
\text { by teacher's own perception } \\
\text { that teaching mathematics } \\
\text { through children's literature } \\
\text { makes the teaching more } \\
\text { engaging and fun }\end{array}$ & $\begin{array}{l}\text { "I want to } \\
\text { arouse } \\
\text { student's } \\
\text { learning } \\
\text { motivation." }\end{array}$ & $76(46.6 \%)$ & $41(45.1 \%)$ & $35(48.6 \%)$ \\
\hline $\begin{array}{l}\text { 2. Encouraged and inspired } \\
\text { by teacher's own perception } \\
\text { that teaching mathematics } \\
\text { through children's literature } \\
\text { helps children to make mean- } \\
\text { ingful connections between } \\
\text { their mathematics learning } \\
\text { and their everyday life }\end{array}$ & $\begin{array}{l}\text { "It can con- } \\
\text { nect life } \\
\text { experience } \\
\text { and math." }\end{array}$ & $7(4.3 \%)$ & $4(4.4 \%)$ & $3(4.2 \%)$ \\
\hline $\begin{array}{l}\text { 3. Encouraged and inspired by } \\
\text { teacher's own perception that } \\
\text { teaching mathematics through } \\
\text { children's literature can help } \\
\text { to develop children's math- } \\
\text { ematical understanding and } \\
\text { word problem solving skill }\end{array}$ & $\begin{array}{l}\text { "It can } \\
\text { enhance } \\
\text { the level of } \\
\text { mathematics } \\
\text { understand- } \\
\text { ing." }\end{array}$ & $4(2.5 \%)$ & $2(2.2 \%)$ & $2(2.8 \%)$ \\
\hline
\end{tabular}


Table 3 (Continued)

\begin{tabular}{lllll}
\hline Categories & $\begin{array}{l}\text { Examples of } \\
\text { statement }\end{array}$ & $\begin{array}{l}\text { Total number of } \\
\text { teachers (T) }\end{array}$ & $\begin{array}{l}\text { In-service } \\
\text { teachers (IST) }\end{array}$ & $\begin{array}{l}\text { Pre-service } \\
\text { teachers (PST) }\end{array}$ \\
& & $(N=185 / 287)$ & $(N=111 / 190)$ & $(N=74 / 97)$ \\
& & $f^{*}(\%)$ & $f^{*}(\%)$ & $f^{*}(\%)$
\end{tabular}

Theme 2: desire to improve teaching (30.6\%)

4. Encouraged and inspired
by teacher's own perception
that teaching mathematics
through children's literature
is an interesting and innova-
tive concept
5. Encouraged and inspired
by teacher's desire to try
new methods of teaching
mathematics
6. Encouraged and inspired
by teacher's own belief in
the value of cross-curricular
teaching

"I think this
is also an
innovative
teaching
concept."
"Change the
teaching
methods and
self-chal-
lenge."
"I want to
try cross-
disciplinary
teaching
activities."

$33(20.2 \%)$

$22(24.2 \%)$

$11(15.3 \%)$

$11(6.7 \%) \quad 4(4.4 \%)$

$7(9.7 \%)$

teaching

self-chal-

lenge."

$6(3.7 \%)$

$2(2.2 \%)$

$4(5.6 \%)$

teaching

Theme 3: enabling social norms $(9.8 \%)$
7. Encouraged and inspired by key stakeholders (e.g., school leaders, mentors, colleagues, and parents)
8. Encouraged and inspired by recommendations found in the mathematics textbook guides for teachers
"The other teacher succeeded in doing so."
"Teach- ers guide textbooks include some examples."

$\begin{array}{lll}9(5.5 \%) & 2(2.2 \%) & 7(9.7 \%) \\ 7(4.3 \%) & 7(7.7 \%) & 0(0 \%) \\ \end{array}$

Theme 4: love of children's literature (2.5\%)
9. Encouraged and inspired by "Students like children's love of children's to read story literature books."

Theme 5: knowledge of the approach (1.8\%)
10. Encouraged and inspired
"Experiences by teacher training and
continued professional
development graduate school's course"

$3(1.8 \%)$

$3(3.3 \%)$

$0(0 \%)$

Theme 6: availability of resources (1.8\%)
11. Encouraged and inspired
"If I found
some suit-
able picture by the avail
resources
books"

Total $(f)$

163

91

72

Note. $f$ is here taken to refer to the number of teachers who mentioned a particular belief. The teachers were able to state more than one perceived enabler. Beliefs repeated by the same teacher were only counted once 


\section{Key findings}

\subsection{Perceived barriers}

In total, 256 of the 287 teachers responded to the survey question: In your experience, what are the key barriers that stop you from incorporating (more) children's literature in your mathematics teaching? These included the teachers who reported that they never incorporated children's literature in their mathematics teaching and those who have had some experiences. Of these 256 teachers, 180 were in-service teachers and 76 were pre-service teachers. As each teacher was allowed to state more than one perceived barrier, the total number of coding occurrences on perceived barriers $(N=303)$ was higher than the number of survey respondents $(N=256)$. Based on the thematic coding analysis, 11 perceived barriers were identified which could be broadly grouped under five themes, namely Time Constraint, Lack of Pedagogical Knowledge and Confidence, Resource Constraint, Doubts about Outcome Expectancy, and Inhibiting Social Norms (Table 2).

The first theme, time constraint, is made up of three categories, and they collectively account for over half $(53.1 \%)$ of all the coding occurrences on perceived barriers, making it the most predominant cluster of perceived barriers for teachers in Taiwan. As the theme's name suggests, these categories are all related to different ways in which the limited or lack of time are considered to have discouraged teachers from teaching mathematics using children's literature. More specifically, these categories include Limited or lack of teaching (33\%) and Limited or lack of time to plan for lessons using this approach (2.3\%). Several teachers also indicated limited or lack of time as a barrier but did not specifically state in what context they considered having limited or lack of time. Instead of disregarding them as being ambiguous, a decision was made to retain them under the Limited or lack of time (unspecified) category (17.8\%).

The second most predominant theme, Lack of Pedagogical Knowledge and Confidence, is made up of three categories, and they collectively account for $22.8 \%$ of all the coding occurrences on perceived barriers. The first of these categories, Limited or lack of training and experience in the approach, accounts for $15.5 \%$ of all coding occurrences on perceived barriers, followed by Limited or lack of awareness of suitable children's literature for specific mathematical concepts (6.6\%) and Perceived difficulty and/or fear in implementing the approach (0.7\%). Overall, this theme is about a very simple and yet important message, asserting that without the necessary training, teachers would be less likely to teach mathematics using children's literature. Without the training, teachers would not be made aware of suitable and insightful children's literature for mathematics teaching and would not feel confident in teaching mathematics using children's literature.

Theme 3, Resource Constraint (13.2\%) is made up of only one category, namely Limited or lack of suitable children's literature at school. Even if teachers were aware of the wide range of children's literature that could be used for mathematics teaching, it would not mean much if their schools' library does not have such books and/or, for example, they cannot access the stories online. This category is not to be confused with an earlier category (i.e., Limited or lack of awareness of suitable children's literature for specific mathematical concepts) where teachers commented, for example, that "There are few children's literature integrated into mathematics curriculum." As it will be discussed later in this paper, such teachers would only need to put on their mathematical lens - the ability to identify meaningful mathematics teaching and learning opportunities in unlikely sources (Trakulphadetkrai, 2018) — to turn children's literature that does not have an explicit mathematical 
focus into a meaningful mathematics teaching and learning tool. With appropriate training, it is possible that these teachers would no longer be constrained by such a perceived barrier. In contrast, teachers who cited Limited or lack of suitable children's literature at school are likely aware of suitable children's literature but simply do not have access to it.

Theme 4, Doubts about Outcome Expectancy (9.5\%), is concerned with teachers' perceptions that question the effectiveness and suitability of the approach. The theme is made up of three types of doubts: Perceived limitation of the approach for children with limited literacy proficiency and those not interested in reading (5.6\%) where some teachers cited how the use of children's literature in mathematics teaching could be problematic for children who find reading difficult; Perceived incompatibility between children's literature and mathematics teaching (2.6\%) in which some teachers believed that mathematics and literacy are two separate curricular domains; and Perceived incompatibility between the approach and the adopted mathematics textbooks, assessments and school's ethos (1.3\%) where some teachers believed that the approach could distract them and their students from focusing on teaching and learning mathematics in a way that would ensure a high test score, for example.

The fifth and final theme, Inhibiting Social Norms, accounts for $1.3 \%$ of all the coding occurrences on perceived barriers and its presence provides a useful contrast to Enabling Social Norms as one of the perceived enabler's themes to be discussed in the following section. The one category that makes up this theme is Perceived unwillingness of key stakeholders for the approach to be trialled where teachers believed that their attempt to incorporate children's literature in their mathematics teaching would not be received positively by, for example, their school leader, mentor, or parents.

Concerning the perceived barriers, findings indicated that the three most-cited categories alone account for over $60 \%$ of all the codings are Limited or lack of teaching time to incorporate the approach (33\%); Limited or lack of time (unspecified) (17.8\%) and Limited or lack of training and experience in the approach (15.5\%). Ways to address each of these key perceived barriers are discussed in section 5.

Proportionally, most perceived barriers were cited equally by both in- and pre-service teachers. Exceptions are the Limited or lack of training and experience in the approach category where nearly a third of pre-service teachers (28.7\%) cited this barrier, compared to only $10.2 \%$ of the in-service teachers. Another noticeable disparity pertains to the Limited or lack of time (unspecified) category, in which the number of in-service teachers (20.8\%) who cited this barrier was approximately twice of the number of pre-service teachers (10.3\%). This disparity arguably could be due to how in-service teachers might have a better insight into the day-to-day operation of school life and are likely more aware of the different tasks that can easily deplete their time at school.

\subsection{Perceived enablers}

In total, 185 of the 287 teachers responded to the survey question: If you have previously incorporated children's literature in your mathematics teaching, what enabled / encouraged you to do so? Of these 185 teachers, 111 were in-service teachers and 74 were pre-service teachers. Using the thematic coding analysis on the participants' responses, we identified 11 perceived enablers, which could be broadly grouped into six themes, namely Perceived Pedagogical Benefits, Desire to Improve Teaching, Enabling Social Norms, Love of Children's Literature, Knowledge of the Approach, and Availability of Resources (Table 3). 
The first theme, Perceived Pedagogical Benefits, is made up of three categories, and collectively account for more than half (53.4\%) of all coding occurrences on perceived enablers, making it the most predominant cluster of perceived enablers for teachers in Taiwan. This theme is concerned with teachers' perceptions of three key pedagogical benefits of the approach that encouraged them to teach mathematics using children's literature, and these benefits are to help: making mathematics teaching more engaging and fun (46.6\%), making meaningful connections between children's mathematics learning and their everyday life (4.3\%), and developing children's mathematical understanding and word problem-solving skill (2.5\%). An argument could be made that the Perceived Pedagogical Benefits theme here in section 4.2 provides a nice direct contrast to the Doubts about Outcome Expectancy theme in section 4.1. Yet, interestingly, only $9.5 \%$ of the teachers cited perceived barriers relating to the latter theme versus $53.4 \%$ who cited perceived enablers relating to the former theme. One possible interpretation is that as a community of practitioners, the majority of them can see potential benefits of teaching mathematics using children's literature and that only a few of them still have some reservations about the approach.

Theme 2, Desire to Improve Teaching, is made up of three categories: Encouraged and inspired by teacher's own perception that teaching mathematics through children's literature is an interesting and innovative concept (20.2\%), Encouraged and inspired by teacher's desire to try new methods of teaching mathematics (6.7\%), and Encouraged and inspired by teacher's own belief in the value of cross-curricular teaching (3.7\%). More concisely, this theme is concerned with teachers whose main desire is to seek ways to help them improve their mathematics teaching, and if using children's literature could help them achieve that goal, then they would do it.

Theme 3, Enabling Social Norms, accounts for 9.8\% of all the coding on perceived enablers and is made up of two categories: Encouraged and inspired by key stakeholders $(5.5 \%)$ and Encouraged and inspired by recommendations found in mathematics textbook guide for teachers (4.3\%). In the context of this theme, teachers would be encouraged to teach mathematics using children's literature if the encouragement to implement the approach from, for example, their school leaders, mentors, colleagues and/or parents as well as mathematics textbook guide is evident. As previously noted, this theme is a nice contrast to the Inhibiting Social Norms theme found earlier in section 4.1.

Feeling encouraged and inspired by children's love of reading and story picture books makes up the fourth theme, Love of Children's Literature, which accounts for $2.5 \%$ of all the coding occurrences on perceived enablers.

Accounting for $1.8 \%$ of all coding occurrences on perceived enablers, Theme 5 , Knowledge of the Approach, is made up of one category, namely Encouraged and inspired by teacher training and continued professional development. This theme is concerned with teachers who would use children's literature in their mathematics teaching if they know how, highlighting the importance of training-both initial teacher training and continued professional development for pre-service and in-service teachers respectively.

The sixth and final theme, Availability of Resources, accounts for $1.8 \%$ of all coding occurrences on perceived enablers and is made up of one category Encouraged and inspired by the availability of relevant resources. Specifically, teachers would be encouraged to teach mathematics using children's literature if their school's library is stocked with suitable children's literature for mathematics teaching or if they have access to recommendations of these stories.

In particular, findings revealed the two most-cited perceived enablers which account for almost $70 \%$ of all coding occurrences on perceived enablers, and they are: Encouraged 
and inspired by teacher's own perception that teaching mathematics through children's literature makes the teaching more engaging and fun (46.6\%) and Encouraged and inspired by teacher's own perception that teaching mathematics through children's literature is an interesting and innovative concept (20.2\%). Proportionally, almost all perceived enablers were cited equally by both in- and pre-service teachers. An exception is the Encouraged and inspired by teacher's own perception that teaching mathematics through children's literature is an interesting and innovative concept category where relatively more in-service teachers $(24.2 \%)$ cited this enabler, as compared to their pre-service counterparts $(15.3 \%)$. Another exception is related to the category, Encouraged and inspired by recommendations found in the textbook guides for teachers, which accounts for $7.7 \%$ of all coding occurrences on the enablers perceived by in-service teachers, but it was never cited by any of the preservice teachers. Arguably, this disparity is possibly caused by how in-service teachers were much more exposed to the textbook guides for teachers than pre-service teachers were.

\section{Discussion and conclusion}

This study sets out to explore Taiwanese in-service and pre-service primary school teachers' beliefs concerning the integration of children's literature in mathematics teaching and learning. First of all, the study found that only $2.1 \%$ of the teachers have utilized children's literature frequently in their mathematics teaching (i.e., more than 10 mathematics lessons per year), while the majority have never used children's literature in their mathematics teaching. This is particularly of great concern given the considerable benefits of the integration for mathematics teaching and learning that have been documented in research over the past few decades. However, such a finding is also hardly surprising given that mathematics teachers in Taiwan have not been explicitly encouraged to integrate mathematics and literacy through mathematics story picture book integration until recently (MET, 2019). It is thus critical to better understand Taiwanese teachers' perceptions towards such integration, particularly some of the key perceived barriers to and perceived enablers for the approach, and in the context of this study, Ajzen's (1991) TPB is hereinafter used to help frame the following discussion.

\subsection{Perceived barriers}

This study reveals 11 perceived barriers, which could be broadly grouped under five themes: Time Constraint, Lack of Pedagogical Knowledge and Confidence, Resource Constraint, Doubts about Outcome Expectancy, and Inhibiting Social Norms (Table 2). These themes could be mapped specifically onto the TPB model: attitude toward the behavior, subjective norm, and perceived behavioral control, which influence behavioral intention.

The Time Constraint, Lack of Pedagogical Knowledge and Confidence, and Resource Constraint themes could be mapped onto the Perceived behavioral control construct, which refers to people's perception of the ease or difficulty of performing the behavior of interest. In the context of this study, these three themes are the key perceived barriers (accounting for $89.1 \%$ of all coding occurrences on perceived barriers), which arguably prevent Taiwanese teachers from teaching mathematics using children's literature. Concerning the time constraint, Altieri (2010) and NCTM (2018) highlight that children's mathematics and literacy skills could be built and fostered simultaneously in a time-efficient manner when connecting mathematics and literacy in mathematics teaching and learning through the use of children's 
literature. This arguably indicates that teaching mathematics using children's literature could help teachers to address the lack of time in their teaching. On the other hand, the lack of pedagogical knowledge and confidence is an unsurprising factor of the perceived behavioral control in this study, as over $80 \%$ of the teachers reported that they did not receive any training on integrating children's literature in mathematics teaching (Table 1).

As the guidelines for mathematics curriculum in Taiwan (MET, 2019) demand teachers to emphasize the development of good mathematical literacy skills, it is hoped that more teacher educators will help teachers in Taiwan develop their knowledge and confidence when enriching mathematics teaching and learning using children's literature in a teacher training program. Regarding the resource constraint, it is difficult to know for sure if this perceived barrier is also an actual barrier. While some teachers may be under the impression that there is no appropriate children's literature for mathematics teaching and learning, this could be due to their lack of awareness of such resources. To address this issue at the national level, we would recommend establishing a national database of children's literature for mathematics teaching and learning like that on the MathsThroughStories.org website. Such a database could help Taiwanese teachers to clearly see how many, and which, children's literature published in Taiwanese Mandarin could be used to enhance their mathematics teaching - ideally as categorized by topics and age groups. Even without children's literature with explicit mathematical focus, teachers still could put on the previously noted mathematical lens (Trakulphadetkrai, 2018) to identity meaningful mathematics teaching and learning opportunities from children's literature with only implicit mathematical focus.

Theme 4 (doubting about outcome expectancy) can be mapped onto the attitude toward the behavior construct of the TPB, which considers the extent to which a person has a favorable or unfavourable appraisal of behavior. The barrier in this context indicates that some teachers appear to be doubtful of the effectiveness of the approach. This is, to an extent, not surprising as teachers in Taiwan have not been trained to effectively integrate children's literature in mathematics teaching, and the official national policy recommends them to do so only recently (MET, 2019). The findings showed that $9.5 \%$ of the teachers viewed that the children's difficulty in reading, as well as the incompatibility between children's literature and mathematics teaching and between teaching approach and mathematics textbook, assessment and school's ethos altogether affect their intention to integrate children's literature in mathematics teaching. Nevertheless, Chen et al. (2013) have shown that Taiwanese teachers argued that there are feasible and suitable ways for integrating children's literature in mathematics teaching, and they will consider implementing such integration in the future on account of the potential benefits of the integration for students (see section 2). As student achievement (part of school ethos) is deemed a priority in Taiwan, teachers in Taiwan also may consider the integration as earlier studies have shown that the use of children's literature in mathematics teaching and learning can help increase student mathematics achievement (Hong, 1996; Jennings et al., 1992; Kisker et al., 2012). More recently, the study of Huang and Yang (2021), which developed two sets of non-commercial Taiwanese mathematical story picture books and integrated them into a fourth-grade mathematics classroom, found that not only could they be used to promote students' mathematical learning and understanding, but they also facilitate students' attitudes towards mathematics.

The final theme, Inhibiting Social Norms, can be mapped onto the Subjective norm construct of the TPB, which concerns the social pressure to perform or not to perform the behavior in question. In relation to the teachers' beliefs in this study, it appears that the idea of teaching mathematics using children's literature might not be fully supported by educational stakeholders around them, such as school leaders, mentors, and parents. Accordingly, we hope mathematics teachers should be able to take and demonstrate a good 
pedagogical leadership role in their schools, specifically in persuading the stakeholders to allow and support the manifestation of such integration, considering substantial advantages of the integration elaborated in the earlier section. We also argue that the integration would facilitate interdisciplinary knowledge (Ward, 2005), which is essentially encouraged in the twenty-first century by many educational stakeholders worldwide.

\subsection{Perceived enablers}

We identified 11 perceived enablers that could be grouped into six themes, namely Perceived Pedagogical Benefits, Desire to Improve Teaching, Enabling Social Norms, Love of Children's Literature, Knowledge of the Approach, and Availability of Resources (Table 3). These six themes could also be framed using the TPB model as detailed below. We argue that Theme 1 (Perceived Pedagogical Benefits), Theme 2 (Desire to Improve Teaching) and Theme 4 (Love of Children's Literature) can be nicely mapped onto the Attitude toward the behavior construct in the TPB model, which is related to the extent to which an individual has a favourable or unfavourable appraisal of behavior. The more teachers are aware of potential pedagogical benefits of the approach, the more they are driven to improve their mathematics teaching, and the more children's literature in general are liked by the students, the more likely these teachers would be inclined to enhance their mathematics teaching using children's literature.

Theme 5 (Knowledge of the Approach) and Theme 6 (Availability of Resources) can be mapped onto the Perceived behavioral control construct in the TPB model, explaining the ease or difficulty of performing the behavior of interest. This concern indicates that the more knowledge and awareness of the approach the teachers have and the more available the children's literature for mathematics teaching is, the more likely that these teachers would be likely to enrich their mathematics teaching using children's literature. Finally, Theme 3 (Enabling Social Norms) can be mapped onto the Subjective norm construct in the TPB model, which elucidates the behaviors expected or supported by people around the teachers. In this context, the teachers acknowledged that the approval from school leaders, mentors, colleagues, and parents, as well as the inclusion of such integration in mathematics textbook guides are necessary, and thus, these factors cannot be underestimated.

\subsection{Comparison of findings}

Several interesting comparisons between our study's findings and those of the Irish study (Prendergast et al., 2019) can be made. Firstly, a noticeably higher proportion of Taiwanese in-service teachers $(68.4 \%)$ and pre-service teachers $(79.4 \%)$ reported that they have never used children's literature in their mathematics teaching when comparing with Irish inservice teachers (47.1\%) and pre-service teachers (53.4\%). In contrast, a noticeably lower proportion of Taiwanese in-service teachers $(2.6 \%)$ and pre-service teachers $(1 \%)$ reported that they have frequently used children's literature (i.e., more than 10 mathematics lessons within that academic year) when comparing with Irish in-service teachers (17.6\%) and pre-service teachers $(3.9 \%)$. These initial comparisons of the contextual data revealed that Taiwanese teachers are either much less aware of the idea of teaching mathematics using children's literature or as equally aware of the approach as their Irish counterparts, but, for some reasons, are much less likely to be able to implement the approach as part of their teaching. Such findings could be due to the fact that Taiwan's previous national curriculum did not highlight the importance of integrating story picture books into mathematics 
teaching and learning (MET, 2008). Moreover, mathematics teaching and learning in Taiwan are highly content oriented and examination driven (Graf \& Leung, 2000). In addition, teachers in Taiwanese mathematics classes usually follow the contents of textbooks and cover all topics included in the textbooks, as they have high pressure to focus on covering the prescribed content of the mathematics curriculum. These contexts of teaching and learning could explain why only a small proportion of teachers in Taiwan appeared to have related experience in using story picture books as part of their mathematics teaching.

Concerning the perceived barriers, the current study yields 11 perceived barriers while the Irish study yields 13 perceived barriers. Both studies are, however, able to classify their perceived barriers into one of the same five broad themes: Time Constraint, Lack of Pedagogical Knowledge and Confidence, Resource Constraint, Doubts about Outcome Expectancy, and Inhibiting Social Norms. This is very interesting as it seems to show that regardless of the socio-cultural context of the studies, the same cluster of five themes persists. That said, proportionally, many more Taiwanese teachers $(53.1 \%)$ cited Time Constraint perceived barriers (making this their top theme), with only $23.4 \%$ of Irish teachers cited perceived barriers relevant to that theme. One conjecture is that Taiwanese teachers could be under a lot more pressure to cover their mathematics curriculum as laid out in the mathematics textbooks, and thus may feel less able or less inclined to devote time to implement any teaching approach that does not deem to be time efficient. In fact, one perceived barrier that is unique to this study and was not found in the Irish study is Perceived incompatibility between the approach and the adopted mathematics textbooks, assessments and school's ethos, which belongs to the Doubts about Outcome Expectancy theme. While only a few teachers in the current study cited the category, it arguably highlights that some Taiwanese teachers, just simply do not have time for any teaching approach that does not readily help them to cover the contents laid out in their mathematics textbooks. Again, as this perceived barrier was highlighted by only a handful of teachers, cautions must be taken when making inferences from this result.

Concerning the perceived enablers, while the Irish study classified its 12 perceived enablers into one of the three themes (i.e., Perceived Pedagogical Benefits, Enabling Social Norms and Love of Children's Literature), we found the Irish study's Perceived Pedagogical Benefits theme too broad, and decided to create an additional theme, called Desire to Improve Teaching. Perceived enablers, such as Encouraged and inspired by teacher's desire to try new methods of teaching mathematics and Encouraged and inspired by teacher's own belief in the value of cross-curricular teaching that were once grouped under the Perceived Pedagogical Benefits theme in the Irish study are now grouped in the new Desire to Improve Teaching theme. Similarly, the current study also found the Irish study's Enabling Social Norms theme to be too broad as it encompassed perceived enablers, such as Encouraged and inspired by training and Encouraged and inspired by online resources. For the present study, two new themes are created: 1) Knowledge of the Approach for the following perceived enabler, Encouraged and inspired by teacher training and continued professional development, and 2) Availability of Resources for the following perceived enabler, Encouraged and inspired by the availability of relevant resources. These changes were influenced, to an extent, by Ajzen's (1991) TPB framework. For example, now that the current study's Enabling Social Norms theme consists of only the following two perceived enablers: Encouraged and inspired by key stakeholders (e.g., school leaders, mentors, colleagues, and parents) and Encouraged and inspired by recommendations found in the mathematics textbook guides for teachers, this would allow the Enabling Social Norms theme to align much more closely to the Subjective norm component of the TPB (i.e., the perceived social pressure to perform or not to perform a behavior) - something which would not have been possible if Encouraged and inspired by teacher training and continued professional 
development and Encouraged and inspired by the availability of relevant resources were still part of the Enabling Social Norms theme.

\section{Implication and significance of the study}

This study reveals some of the key factors reported by Taiwanese primary school teachers which can affect their decision on whether or not to integrate children's literature in mathematics teaching. Approximately $89.1 \%$ of the responses are associated with time constraint, lack of pedagogical knowledge and confidence, and resource constraint, which account for the key barriers to manifest the integration. In this regard, there is serious concern and need for establishing relevant teacher training for both in- and pre-service teachers focusing on how to integrate the children's literature more effectively. On the other hand, $89.5 \%$ of the responses are classified as perceived pedagogical benefits, desire to improve teaching, love of children's literature, which could be regarded as the key enablers for taking the integration into account. This notion shows that teachers in Taiwan admit that integrating children's literature may be a promising alternative strategy or approach to be employed in mathematics teaching and learning.

The findings of this study provide empirical evidence for the Ministry of Education in Taiwan to see just how infrequently primary school teachers in Taiwan enrich their mathematics teaching using children's literature. To address some of these key perceived barriers as found in this study, national efforts to raise teachers' awareness regarding the pedagogical benefits of enriching mathematics teaching using children's literature should be led by the Ministry, for example, through a series of government-funded Continuing Professional Development workshops. Moreover, mathematics teachers should be encouraged to consider existing free on-line resources, such as those available on the MathsThroughStories.org website, to provide supports for them when attempting to integrate children's literature in their teaching.

Ultimately, the significance of this study is two-fold. Firstly, the study offers a wide range of perceived barriers and enablers held by teachers, specifically in Taiwan representing the Asian socio-cultural contexts, in relation to integrating children's literature in mathematics teaching and learning as well as some insights on how to address these barriers and enablers. Moreover, we argue that the perceived barriers and enablers revealed in this study could be considered the potential barriers to and enablers for implementing an educational reform, as the incorporation of children's literature in mathematics teaching and learning is a current educational reform in Taiwan (MET, 2019). In this context, we argue that most of the study's perceived enablers, which were broadly grouped into several themes, such as, Perceived Pedagogical Benefits, Desire to Improve Teaching, Enabling Social Norms, Knowledge of the Approach, and Availability of Resources (Table 3), could be considered the potential enablers for the concrete implementation of an educational reform. Likewise, the 11 perceived barriers, which have been broadly grouped under five themes: Time Constraint, Lack of Pedagogical Knowledge and Confidence, Resource Constraint, Doubts about Outcome Expectancy, and Inhibiting Social Norms (Table 2), could also be considered as potential barriers to the concrete implementation of an educational reform. For example, barriers to adopting specific pedagogical strategies and/or resources, such as time constraint and resource constraint, can also be found in other studies not specifically in the field of mathematics education, for instance, Underwood's (2012) study on Japanese teachers' views on the integration of grammar with communication-oriented teaching, and Zyad's (2016) study on Moroccan teachers' views on the use of ICT in their teaching. Such similarity in findings, regardless of which pedagogical strategy, resource, or 
socio-cultural context, further strengthens that the findings of the present study could also be relevant when examining other types of education reform. Eventually, we hope that educational stakeholders worldwide may consider addressing the perceived barriers and facilitating the perceived enablers appropriately in the teacher education program when making the effort to incorporate children's literature in mathematics teaching and learning and/or to implement an education reform.

\section{Limitation and direction for future research}

Given the study's sample size, the findings cannot be generalized but instead could provide further insights from an Asian perspective about teachers' belief on the integration of children's literature in mathematic teaching. Moreover, as the study relied solely on survey responses, we were unable to probe these responses further. The use of additional data collections (e.g., interviews or focus groups) would allow the study to gain further insights into some of the reported responses. Furthermore, it would also have been much clearer for our survey respondents if we have used the term 'story picture books' [故事書] instead of the term 'children's literature' [兒童文學] that was used in our survey questions. This is because a few teachers (particularly those teaching younger children) also include songs, poems and even games as the forms of 'children's literature', which are not the focus of our research. In addition, considering the complexity of cultural differences, there is still a great concern pertaining to whether different cultures have different values when it comes to children's literature-especially when the children's literature are solely translated from its source (e.g., many story picture books used in Asia are translated from English that might be associated with Western cultures) — which could not be answered in this study as this study only focuses on teachers' beliefs concerning perceived barriers to and enablers for the integration of children's literature in mathematics teaching and learning. Finally, it could have been useful to clarify to our survey respondents that children's literature for mathematics teaching and learning could include those with an explicit mathematical focus and those without one, as if a teacher thought that what the current study focused on is children's literature with an explicit mathematical focus only, then this might have influenced their response, for example, by stating that their school lacks such resources, when in fact, their school might have children's literature without an explicit mathematical focus that can be meaningfully used to teach mathematical concepts.

Acknowledgements We would like to thank the University of Reading for funding the Open Access fee for this article.

\section{Declarations}

Conflict of interests The authors have no conflict of interest to declare.

Open Access This article is licensed under a Creative Commons Attribution 4.0 International License, which permits use, sharing, adaptation, distribution and reproduction in any medium or format, as long as you give appropriate credit to the original author(s) and the source, provide a link to the Creative Commons licence, and indicate if changes were made. The images or other third party material in this article are included in the article's Creative Commons licence, unless indicated otherwise in a credit line to the material. If material is not included in the article's Creative Commons licence and your intended use is not permitted by statutory regulation or exceeds the permitted use, you will need to obtain permission directly from the copyright holder. To view a copy of this licence, visit http://creativecommons.org/licenses/by/4.0/. 


\section{References}

Ajzen, I. (1991). Theory of planned behavior. Organizational Behavior and Human Decision Processes, $50,179-211$.

Ajzen, I. (2012). The theory of planned behavior. In P. A. M. van Lange, A. W. Kruglanski, \& E. T. Higgins (Eds.), Handbook of theories of social psychology, 1 (pp. 438-459). SAGE Publications Ltd.

Alazzi, K. F. (2006). Perceptions of preservice teachers toward children's literature. Essays in Education, $18,1-16$.

Altieri, J. (2010). Literacy+ Math. Liturgical Press.

Bintz, W. P., Moore, S. D., Wright, P., \& Dempsey, L. (2011). Using literature to teach measurement. The Reading Teacher, 65(1), 58-70. https://doi.org/10.1598/RT.65.1.8

Burns, M. (1992). About teaching mathematics: A K-8 resource. Math Solutions.

Bussi, M. G., Funghi, S., \& Ramploud, A. (2020). Mathematics teachers' cultural beliefs. In D. Potari \& O. Chapman (Eds.), International handbook of mathematics teacher education (pp. 131-154). Brill Sense.

Casey, B., Kersh, J. E., \& Young, J. M. (2004). Storytelling sagas: An effective medium for teaching early childhood mathematics. Early Childhood Research Quarterly: Special Issue on Mathematics and Science, 19, 167-172.

Chan, K. W., \& Elliot, R. G. (2004). Relational analysis of personal epistemology and conceptions about teaching and learning. Teaching and Teacher Education, 20, 817-831.

Chen, T.-C., Tsai, M.-H., Wu, M.-F., \& Chang, Y.-L. (2013). Integrating picture books into mathematical teaching for lower graders' learning of the concept of multiple (in Chinese). Journal of Taoyuan Innovation, 33, 259-273.

Clarke, D. (2002). Making measurement come alive with a children's storybook. Australian Primary Mathematics Classroom, 7(3), 9-13.

Elia, I., van den Heuvel-Panhuizen, M., \& Georgiou, A. (2010). The role of pictures in picture books on children's cognitive engagement with mathematics. European Early Childhood Education Research Journal, 18(3), 125-147. https://doi.org/10.1080/1350293X.2010.500054

Graf, K. D., \& Leung, F. K. S. (2000). The thirteenth ICMI study on mathematics education in different cultural traditions. Educational Studies in Mathematics, 43, 95-116.

Handal, B., \& Herrington, A. (2003). Mathematics teachers' beliefs and curriculum reform. Mathematics Education Research Journal, 15(1), 59-69.

Hassinger-Das, B., Jordan, N. C., \& Dyson, N. (2015). Reading stories to learn math: Mathematics vocabulary instruction for children with early numeracy difficulties. The Elementary School Journal, 116(2), 242-264. https://doi.org/10.1086/683986

Hong, H. (1996). Effects of mathematics learning through children's literature on math achievement and dispositional outcomes. Early Childhood Research Quarterly, 11, 477-494. https://doi.org/10.1016/ S0885-2006(96)90018-6

Huang, J. W., \& Yang, D. C. (2021). Development and trial of children's picture books in Mathematics. Curriculum \& Instruction Quarterly, 24(1), 201-234. (In Chinese).

Jennings, C. M., Jennings, J. E., Richey, J., \& Dixon-Krauss, L. (1992). Increasing interest and achievement in mathematics through children's literature. Early Childhood Research Quarterly, 7(2), 263276. https://doi.org/10.1016/0885-2006(92)90008-M

Kisker, E. E., Lipka, J., Adams, B. L., Rickard, A., Andrew-Ihrke, D., Yanez, E. E., \& Millard, A. (2012). The potential of a culturally based supplemental mathematics curriculum to improve the mathematics performance of Alaska Native and other students. Journal for Research in Mathematics Education, 43(1), 75-113.

Leung, F. K. S. (2001). In search of an East Asian identity in mathematics education. Educational Studies in Mathematics, 47, 35-51.

Leutwyler, B., Mantel, C., Petrović, D. S., Dimitrijević, B. M., \& Zlatković, B. (2014). Teachers' beliefs about intercultural education: Different levels of intercultural sensitivity in schooling and teaching. Educational Research, 5(8), 280-289. https://doi.org/10.14303/er.2014.196.

Lui, K. W., \& Leung, F. K. S. (2012). Textbooks and cultural traditions: A comparative case study of Berlin and Hong Kong. The Mathematics Educator, 13(2), 55-72.

McAndrew, E. M., Morris, W. L., \& Fennell, F. (2017). Geometry-related children's literature improves the geometry achievement and attitudes of second-grade students. School Science and Mathematics, 117(1-2), 34-51.

McDowell, M. (1976). Fiction for children and adults: Some essential differences. In G. Fox, G. Hammond, T. Jones, F. Smith, \& K. Skerek (Eds.), Writers, critics, and children (pp. 140-156). Heinemann.

Ministry of Education in Taiwan [MET]. (2008). Nine-year-integrated mathematics curriculum standards for national schools from grade 1 to 9 in Taiwan [in Chinese]. Ministry of Education. 
Ministry of Education in Taiwan [MET]. (2019). Presentation of the 2018 Guidelines of Mathematics Curriculum. Taiwan Ministry of Education. https://cirn.moe.edu.tw/Upload/ckfile/files/新課綱推 動/數學領域課程綱要宣講公播版簡報(109_03).pdf.

Moyer, P. S. (2000). Communicating mathematically: Children's literature as a natural connection. The Reading Teacher, 54(3), 246-255.

Mullis, I. V. S., Martin, M. O., Foy, P., \& Hooper, M. (2016). TIMSS 2015 international results in mathematics. http://timssandpirls.bc.edu/timss2015/international-results/.

Mullis, I. V. S., Martin, M. O., Foy, P., Kelly, D. L., \& Fishbein, B. (2020). TIMSS 2019 international results in mathematics and science. https://timssandpirls.bc.edu/timss2019/international-results/.

National Council of Teachers of Mathematics. (1992). How to use children's literature to teach mathematics. NCTM.

National Council of Teachers of Mathematics. (2000). Principles and standards for school mathematics. NCTM.

National Council of Teachers of Mathematics. (2004). Exploring mathematics through literature: Articles and lessons for Prekindergarten through Grade 8. NCTM.

National Council of Teachers of Mathematics. (2018). Deepening students' mathematical understanding with children's literature. NCTM.

Nordlöf, C., Hallström, J., \& Höst, G. E. (2017). Self-efficacy or context dependency?: Exploring teachers' perceptions of and attitudes towards technology education. International Journal of Technology and Design Education, 29, 123-141. https://doi.org/10.1007/s10798-017-9431-2

Pajares, M. F. (1992). Teachers' beliefs and educational research: Cleaning up a messy construct. Review of Educational Research, 62(3), 307-332.

Philipp, R. A. (2007). Mathematics teachers' beliefs and affect. In F. K. Lester (Ed.), Second handbook of research on mathematics teaching and learning (pp. 257-315). Information Age.

Polly, D., McGee, J. R., Wang, C., Lamber, R. G., Pugalee, D. K., \& Johnson, S. (2013). The association between teachers' beliefs, enacted practices, and student learning in mathematics. The Mathematics Educator, 22(2), 11-30.

Prendergast, M., Harbison, L., Miller, S., \& Trakulphadetkrai, N. V. (2019). Pre-service and in-service teachers' perceptions on the integration of children's literature in mathematics teaching and learning in Ireland. Irish Educational Studies, 38(2), 157-175.

Purpura, D. J., Napoli, A. R., Wehrspann, E. A., \& Gold, Z. S. (2017). Causal connections between mathematical language and mathematical knowledge: A dialogic reading intervention. Journal of Research on Educational Effectiveness, 10, 116-137. https://doi.org/10.1080/19345747.2016. 1204639

Trakulphadetkrai, N. V. (2015). The construction of the 'Primary Teachers' Beliefs concerning the Integration of Children's Literature in Mathematics Learning and Teaching' (PTB-ICLMLT) Framework: Findings from a pilot study. Paper presented at the British Educational Research Association (BERA) Annual Conference, Belfast, UK, 15th-17th September 2015.

Trakulphadetkrai, N. V. (2018). Story picture books as a mathematics teaching and learning tool. Primary Mathematics, 22(2), 3-7.

Trakulphadetkrai, N. V., Courtney, L., Clenton, J., Treffers-Daller, J., \& Tsakalaki, A. (2020). The contribution of general language ability, reading comprehension and working memory to mathematics achievement among children with English as additional language (EAL): An exploratory study. International Journal of Bilingual Education and Bilingualism, 23(4), 473-487.

Underwood, P. R. (2012). Teacher beliefs and intentions regarding the instruction of English grammar under national curriculum reforms: A theory of planned behaviour perspective. Teaching and Teacher Education, 28(6), 911-925.

van den Heuvel-Panhuizen, M., \& Elia, I. (2013). The role of picture books in young children's mathematics learning. In L. D. English \& J. T. Mulligan (Eds.), Reconceptualizing early mathematics learning (pp. 227-251). Springer.

van den Heuvel-Panhuizen, M., Elia, I., \& Robitzsch, A. (2016). Effects of reading picture books on kindergartners' mathematics performance. Educational Psychology, 36(2), 323-346.

Ward, R. A. (2005). Using literature to inspire K-8 preservice teachers' future mathematics pedagogy. The Reading Teacher, 59(2), 132-143.

Zyad, H. (2016). Integrating computers in the classroom: Barriers and teachers' attitudes. International Journal of Instruction, 9(1), 65-78.

Publisher's Note Springer Nature remains neutral with regard to jurisdictional claims in published maps and institutional affiliations. 


\section{Authors and Affiliations}

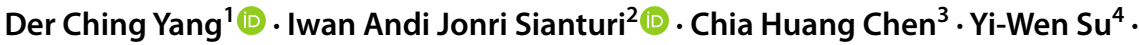 Natthapoj Vincent Trakulphadetkrai ${ }^{5}$ iD}

Der Ching Yang

dcyang@mail.ncyu.edu.tw

Iwan Andi Jonri Sianturi

sianturi@iu.edu

Chia Huang Chen

chench1109@mail.ntcu.edu.tw

Yi-Wen Su

yiwen@utaipei.edu.tw

1 Graduate Institute of Mathematics and Science Education, National Chiayi University, No. 85, Wen Lung, Ming-Hsiung, Chiayi 621, Taiwan, Republic of China

2 Department of Curriculum and Instruction, Indiana University-Bloomington, Wright Education Building, 201 N. Rose Ave., Bloomington, IN 47405, USA

3 Department of Mathematics Education, National Taichung University of Education, 140, Min-Sheng Road, Taichung 40306, Taiwan, Republic of China

4 Department of Mathematics, University of Taipei, No.1, Ai-Guo West Road, Taipei 10048, Taiwan, Republic of China

5 Institute of Education, University of Reading, 4 Redlands Road, Reading RG1 5EX, UK 